\title{
Use of CD137 up-regulation to identify T cell receptors specifically reactive with mutated tumor associated antigens from tumor infiltrating lymphocytes
}

\author{
Maria Parkhurst ${ }^{1 *}$, Alena Gros ${ }^{2}$, Pasetto Anna ${ }^{3}$, Eric Tran ${ }^{3}$, Jessica S Crystal ${ }^{4}$, Todd Prickett ${ }^{1}$, Paul Robbins ${ }^{1}$, \\ Steven A Rosenberg ${ }^{5}$
}

From 30th Annual Meeting and Associated Programs of the Society for Immunotherapy of Cancer (SITC 2015) National Harbor, MD, USA. 4-8 November 2015

\section{Background}

The adoptive transfer of tumor infiltrating lymphocytes (TIL) can mediate the regression of metastatic melanoma. In addition, the adoptive transfer of lymphocytes genetically modified to express tumor reactive $\mathrm{T}$ cell receptors (TCRs) can mediate tumor regression. Many $\mathrm{T}$ cells from TIL recognize mutated antigens expressed only on the autologous patient's tumors. Therefore, we attempted to isolate TCRs reactive with unique mutated antigens so that we might eventually be able to treat patients with autologous $\mathrm{T}$ cells genetically modified to express those TCRs.

\section{Methods}

Mutations in tumors were identified using whole exome sequencing and/or RNA sequencing. Tandem minigene (TMG) constructs containing 12-24 minigenes were synthesized, each encoding the mutated amino acid flanked by 12 amino acids on both sides. RNAs encoding the TMGs were in vitro transcribed and electroporated into autologous dendritic cells (DCs). Recognition of TMGs by TIL was evaluated on the basis of IFN- $\gamma$ secretion and CD137 expression after overnight coculture with the electroporated DCs. Subsequently, mutation reactive $\mathrm{T}$ cells were enriched from TIL by sorting for CD137+ T cells after overnight coculture with the electroporated DCs and were expanded in vitro with anti-CD3 and IL-2. Dominant TCR $\alpha$ and $\beta$ chain sequences were identified in the enriched mutation reactive populations,

${ }^{1} \mathrm{NIH} / \mathrm{NCl} /$ Surgery Branch, Bethesda, MD, USA

Full list of author information is available at the end of the article and retroviruses encoding those TCRs were used to transduce human PBL to determine if they mediated recognition of the mutated antigen.

\section{Results}

Thus far, using these techniques we have isolated mutation reactive TCRs from 6 different patients with metastatic melanoma as described in the attached table. We are currently extending these techniques to identify mutation reactive TCRs for patients with other cancers including those of the gastrointestinal tract, breast, and ovaries. We are also developing clinical reagents to treat

Table 1 Mutation reactive TCRs identified by CD137 upregulation.

\begin{tabular}{lll}
\hline Patient & Mutated antigen & $\begin{array}{l}\text { \# of independent } \\
\text { TCRs }\end{array}$ \\
\hline 3466 & COL18A1 & 1 \\
3466 & ERBB2 & 1 \\
3903 & KIAA1279 & 3 \\
3903 & KIAA1967 & 1 \\
3903 & PHKA1 & 1 \\
3784 & FLNA & 1 \\
3784 & KIF16B & 3 \\
3678 & FBOX21 & 1 \\
3678 & RECQL5 & 2 \\
3716 & Not yet identified at individual gene & 1 \\
& level & \\
4000 & Not yet identified at individual gene & Up to 4 \\
& level & \\
\hline
\end{tabular}


patients with TCRs that recognize unique mutations on autologous tumor cells.

\section{Authors' details}

${ }^{1} \mathrm{NIH} / \mathrm{NCI} /$ Surgery Branch, Bethesda, MD, USA. ${ }^{2} \mathrm{NCI} / \mathrm{NIH}$, Bethesda, MD, USA.

${ }^{3}$ Surgery Branch/National Cancer Institute / National Institutes of Health,

Bethesda, MD, USA. ${ }^{4} \mathrm{NCI} / \mathrm{NIH}$, Rutgers Robert Wood Johnson Medical School, New Brunswick, NJ, USA. ${ }^{5} \mathrm{NIH} / \mathrm{NCl}$, Bethesda, MD, USA.

Published: 4 November 2015

doi:10.1186/2051-1426-3-S2-P40

Cite this article as: Parkhurst et al: Use of CD137 up-regulation to identify $T$ cell receptors specifically reactive with mutated tumor associated antigens from tumor infiltrating lymphocytes. Journal for ImmunoTherapy of Cancer 2015 3(Suppl 2):P40.

Submit your next manuscript to BioMed Central and take full advantage of:

- Convenient online submission

- Thorough peer review

- No space constraints or color figure charges

- Immediate publication on acceptance

- Inclusion in PubMed, CAS, Scopus and Google Scholar

- Research which is freely available for redistribution

Submit your manuscript at www.biomedcentral.com/submit 